\title{
BMJ Open My Home is My Marae: Kaupapa Māori evaluation of an approach to injury prevention
}

\author{
Brooke Hayward, ${ }^{1}$ Mataroria Lyndon, ${ }^{1}$ Luis Villa, ${ }^{1}$ Dominic Madell, ${ }^{1}$ \\ Andrea Elliot-Hohepa, ${ }^{2}$ Lyndsay Le Comte ${ }^{1}$
}

To cite: Hayward B,

Lyndon M, Villa L, et al. My Home is My Marae: Kaupapa Māori evaluation of an approach to injury prevention. BMJ Open 2017;7:e013811. doi:10.1136/bmjopen-2016013811

- Prepublication history and additional material is available. To view please visit the journal (http://dx.doi.org/ 10.1136/bmjopen-2016013811).

Received 26 August 2016 Revised 9 January 2017 Accepted 2 February 2017

CrossMark

${ }^{1}$ Ko Awatea, Counties

Manukau Health, Auckland, New Zealand

${ }^{2}$ OTS Consulting, Rotorua, New Zealand

Correspondence to Dr Dominic Madell; dom.madell@middlemore.co. $\mathrm{nz}$

\section{ABSTRACT}

Objective: The objective of this study was to evaluate the New Zealand Accident Compensation Corporation's (ACC) 'My Home is My Marae' approach to injury prevention for whānau (families).

Setting: Over an 18 month period from November 2013 to June 2014, 14 'My Home is My Marae' trials were conducted across the South Auckland and Far North regions of New Zealand. ACC engaged with local Māori providers of healthcare, education and social services to deliver the home safety intervention.

Participants: Participants of this evaluation were a purposive sample of 14 staff from six provider organisations in South Auckland and the Far North regions of New Zealand.

Methods: Kaupapa Māori theory-based evaluation and appreciative inquiry methodologies underpinned the evaluation. Interview participants led discussions about strengths and weaknesses of the approach, and partnerships with ACC and other organisations. The evaluation was also supported by pre-existing information available in project documentation, and quantitative data collected by Māori providers.

Results: Five key critical success factors of 'My Home is My Marae' were found from interviews: mana tangata (reputation, respect and credibility); manākitanga (showing care for people); kānohi-ki-tekānohi (face-to-face approach); capacity building for kaimahi, whānau and providers and 'low or no cost' solutions to hazards in the home. Data collected for the Far North area showed that $76 \%$ of the hazards identified could be resolved through 'low or no cost' solutions. Unfortunately, similar data were not available for South Auckland.

Conclusions: Injury prevention or health promotion approaches that seek to engage with whānau and/or Māori communities would benefit from applying critical success factors of 'My Home is My Marae'.

\section{INTRODUCTION}

In New Zealand, as in other high-income countries, unintentional injuries represent a significant public health problem causing death, disability, financial and psychological cost. ${ }^{1}$ The WHO recognises the strong link

\section{Strengths and limitations of this study}

- Kaimahi (staff) shared the perspectives or experiences of whānau (family), but the evaluation did not involve the direct participation of whānau who had completed home safety audits alongside kaimahi.

- Provider organisations that participated in this evaluation were selected by ACC, and it is possible that provider organisations not involved in the evaluation could have had different experiences that were not captured.

- While 'low or no cost' solutions used in this programme were identified as potentially highly cost-effective for ACC, a specific cost-benefit analysis was not carried out.

- Incomplete quantitative data meant that it was not possible to draw robust conclusions regarding the reach of the programme and also presented difficulties in being able to compare different patterns in the hazards identified across the Far North and South Auckland regions.

between unintentional injuries and social deprivation, with more socially deprived groups, such as Māori, having the highest incidence of unintentional injuries. ${ }^{2}$

Adult Māori (aged 15-64 years) in New Zealand have higher rates of hospitalisation (1788.0 per 100000 compared to 1104.5 per 100000 ; RR 1.62, $95 \%$ CI 1.59 to 1.65 ) and mortality (42.8 per 100000 compared to 18.7 per 100000 ; RR 2.29. 95\% CI 2.05 to 2.56) than adult non-Māori due to unintentional injury. ${ }^{3}$ Further, research by Mauri Ora Associates [ref. 4, p. 6] demonstrated that Māori are frequently unaware of the "services and benefits to which they are entitled" through the Accident Compensation Corporation (ACC) and have lower rates of access to health services, including ACC services, than non-Māori. Māori represent $14.6 \%$ of the total New Zealand population, and $11.6 \%$ of total ACC claims between 2004 and 2009 were from this ethnic group. ${ }^{5}$ 
The home is the site in which the majority of injuries leading to ACC claims occur. ${ }^{6}$ From 2014 to 2015, one in five people in South Auckland made a claim for an injury in the home. ${ }^{6}$ South Auckland, including Manukau City, Franklin and Papakura Districts, has a population of 524505 , with one in six people being Māori. Northland, which includes the Far North, Whangerei and Kaipara Districts, has a population of 151 692, with one in three people being Māori. From 2014 to 2015, one in three people in Northland made a claim for an injury that occurred in their home. ${ }^{6}$ Further, unintentional injuries are responsible for one out of three disabilities suffered by adult Māori. ${ }^{7}$ Subsequently, prevention of injuries in the home is a key priority area for ACC and they are working to achieve effective injury prevention among whānau and Māori communities through partnering with hapu/iwi and key Māori stakeholders (please see online supplementary Appendix 1 for a glossary of Māori words). 'My Home is My Marae' is delivered in partnership with local Māori health, social or community services, in South Auckland and Far North communities.

'My Home is My Marae' was informed by Māori models of health and what is known to work for Māori from previous injury prevention initiatives and available literature. The approach aims to reduce the risk, incidence or severity of injury in the home among Māori communities by empowering whānau with the knowledge and skills they need to identify hazards in their home environment, and to take continued action to minimise, isolate or eliminate hazards in their home. 'My Home is My Marae' aimed to work with the Māori working age population (25-64 years of age), who are known to be at most risk of a fall at home. ${ }^{6}$ The approach also aimed to be inclusive of all whānau, from tamariki to tūnohunohu, who reside at the same whare of those in the working age population.

Over an 18 month period from November 2013 to June 2014, 14 'My Home is My Marae' trials were conducted across the South Auckland and the Far North regions. ACC engaged with local Māori providers of healthcare, education and social services to deliver the home safety intervention, as it was considered that there would be a greater chance of success with messages coming via established, trusted and local channels. After commitment from the providers was gained, kaimahi were trained by ACC's injury prevention consultants to conduct home safety audits. This training involved equipping kaimahi with the knowledge, skills and resources to capacitate whānau to identify and reduce hazards that risk injury in the whare, through the implementation of 'low or no cost' solutions. 'Low or no cost solutions' included, for example, tidying up or reducing clutter such as shoes at the front or back door, tying electrical cables together, removing hazards from walkways in living spaces, moving poisonous household items out of the reach of young children and ensuring spills were cleaned up before anyone slipped. Using low or no cost solutions aimed to make addressing hazards in the home affordable for all whānau.

Following training, kaimahi worked together with local whānau to conduct the safety audits in their homes, to raise awareness of hazards in the home and to assist them in keeping their whānau safe. This involved the use of standardised ACC collateral including home safety checklists and teaching aids. The main aspects that contributed to the home safety audit are depicted in figure 1. The approach also required that providers maintained whānau engagement and follow-up by returning 1-year later to review what changes had been made.

After making small commitments to change in their whare, whānau were provided with a safety product to assist them to further reduce injury risks such as mould/ lichen remover, rug grips/non-slip mats/shower mats/ bath mats, non-slip paint for outdoor steps, cable grips or cord winders, step ladders, latches for windows and cupboards, smoke alarms or handrails. In total, kaimahi from provider organisations visited a total of 646 whare housing 2897 individuals. In South Auckland, 404 whare housing a total of 1882 individuals were visited (mean $=4.7$ people per household), and in the Far North 242 whare housing a total of 1015 individuals were visited (mean $=4.7$ people per household). The original logic model for 'My Home is My Marae' is presented in figure 2 and depicts 'My Home is My Marae' resources ('inputs'), activities or deliverables and expected outcomes.

A Kaupapa Māori evaluation of the 'My Home is My Marae' trials was completed by Ko Awatea at Counties Manukau Health (Auckland, New Zealand). The evaluation focused on identifying critical success factors of the approach, and strengths and weaknesses of these trials in the context of what is known to work well for Māori in injury prevention, and Māori models of health and well-being.

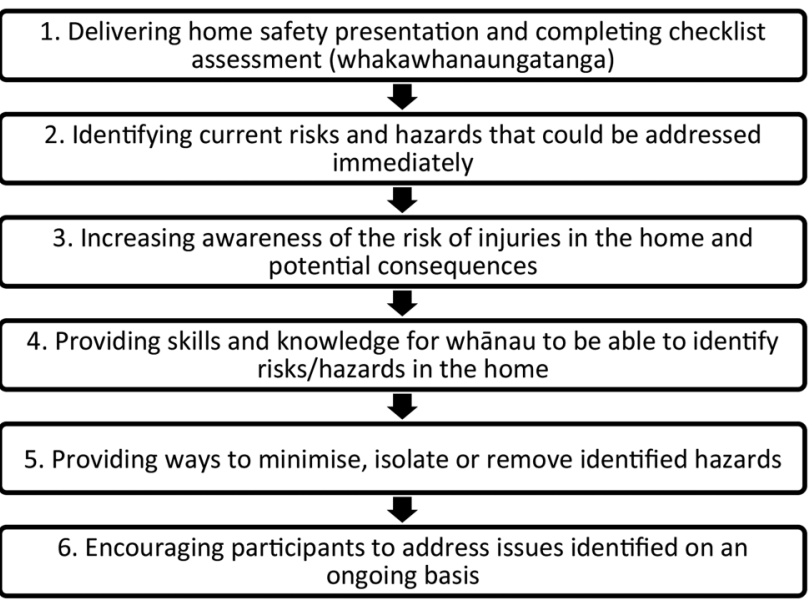

Figure 1 Main aspects of ACC home safety audit. ACC, New Zealand Accident Compensation Corporation. 

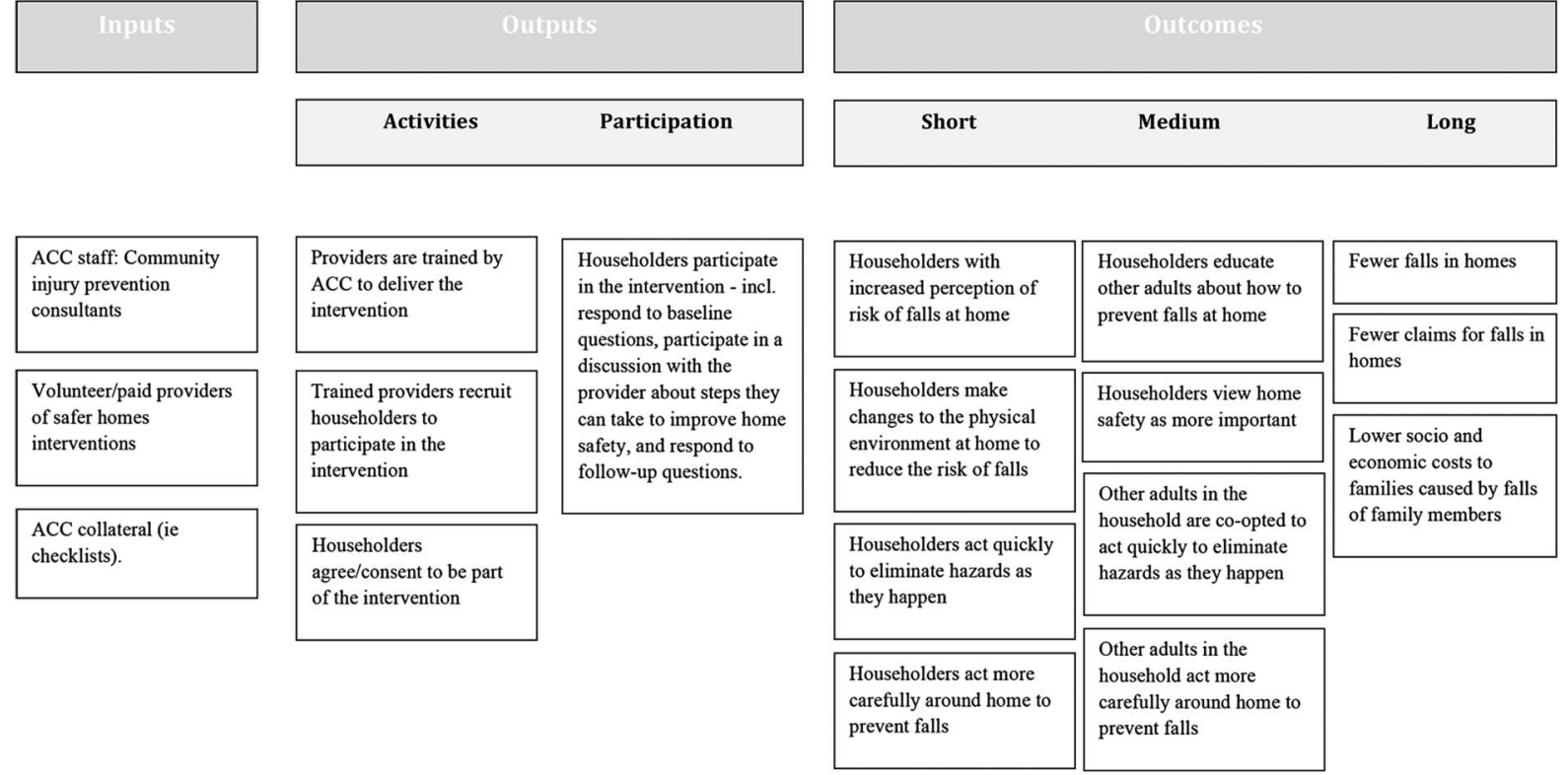

Figure 2 Original logic model for ACC's 'My Home is My Marae' approach to injury prevention (provided February 2014). ACC, New Zealand Accident Compensation Corporation.

\section{METHOD}

The evaluation involved the participation of a purposive sample of 14 kaimahi from six provider organisations who shared their whakāro and experiences delivering 'My Home is My Marae' with the evaluation team. ACC selected providers that had started the trials earliest and therefore had the most well-established trials, and where there were established working relationships with ACC from prior contract work. These were (1) Papatūānuku Kōkiri Marae, (2) Tamaki Makaurau Māori Women's Welfare League, (3) Te Kura Kaupapa Māori a Rohe o Māngere, (4) Tumaitua Whānau Trust, (5) Te Hau Ora o Ngāpuhi (previously Kaikohe) and (6) Te Hau Āwhiowhio o Otāngarei Trust.

Kaupapa Māori theory-based evaluation and appreciative inquiry methodologies underpinned the evaluation. Appreciative inquiry methodology is a 'glass-half full' approach that looks at the best of what already exists, to provide a foundation for thinking about how things could be in an ideal situation. ${ }^{8}$ The approach works on the principle that focussing on what is valued most allows rapid improvements to a situation to be made. With appreciative inquiry, the best aspects of the programme and how it functions are held uppermost in the minds of the evaluators. Kaupapa Māori evaluation approaches aim to normalise Māori worldviews, values, ways of doing things, customs and language across evaluation processes and outputs. ${ }^{9}$ Importantly, they also must aim to make a positive difference among Māori communities. $^{10}$

Kerr $^{11}$ summarised principles of kaupapa Māori research applied throughout this evaluation including control, challenge, culture, connection, change and credibility. These principles were demonstrated in practice by committing to whakawhanaungatanga through pōwhiri to start the evaluation, and throughout the evaluative process involving kōrero, hui and written communication with providers. Throughout the evaluation, evaluators maintained an open door policy with all evaluation participants who were encouraged to share, clarify and raise concerns as they needed.

Evaluators travelled around South Auckland and Far North regions to ensure interviews could be conducted kānohi-ki-te-kānohi. Instead of having predetermined evaluation questioning, kaikōrero led the discussion in the areas of most importance and relevance to their experience. Areas of discussion included, for instance, what was unique about the 'My Home is My Marae' approach, what worked and did not work well for whānau, the success of the partnership approach with ACC and other organisations, their experience of programme resourcing and funding, their experience of co-constructing and then implementing trials and observed positive changes in communities brought about by the programme. Allowing kaikōrero to lead and direct kōrero was underpinned by our desire to value tino rangatiratanga - allowing kaikōrero to exercise control over relevant discussion areas and interview procedures. Mihimihi, whakawhanaungatanga, and kai were also an integral part of the interview process. Time was dedicated by the interview facilitator and kaikōrero to accommodate for this before the korero started.

Māori interviewers, translators and writers enabled extensive use of te reo Māori throughout the interview and written outputs, while also ensuring Māori systems and values were normative in evaluation reporting. A Kaupapa Māori consultant assisted in the design and delivery of the evaluation throughout its duration, to 
contextualise and analyse provider activities and to provide a framework for the discussion of findings. Hui with evaluation participants provided an opportunity for them to challenge preliminary findings and further ensure that Māori values and priorities were at the fore of the evaluation.

A kōrero record was translated (still using te reo Māori to capture cultural terms) and sent to each kaikōrero to review, clarify, amend or share missed information, to ensure the record accurately reflected what they wished to communicate. This allowed time for participants to reflect on the kōrero and add any information they felt was relevant.

Kōrero records were thematically analysed with the aid of NVivo software applying an inductive process. Inductive thematic analysis is a widely applied method for the analysis of qualitative data that involves identifying underlying data-driven patterns or themes in narrative or written materials. ${ }^{12}$ This process involved the evaluation team first familiarising themselves with the records through reading, and in discussion with the kōrero facilitator, who offered valuable insights about the interview process, Māori worldviews and the areas of discussion that kaikōrero were most passionate about. Kōrero records were then coded by one evaluator, and themes developed by three evaluators together with evaluation participants and others as detailed below.

We sought to make meaning from the many experiences and perspectives of kaikōrero by forming patterns of 'truth'. ${ }^{13}$ As provider experiences were community specific, there was not always consensus regarding what worked, what did not and what is the best way forward, and therefore finding consensus was not a focus of analyses. Potential themes were presented to representatives from all provider organisations, ACC's Community injury prevention consultants and ACC's senior research advisor in hui for review and critique. Feedback from this hui was then used to further define and refine key themes.

In addition to the knowledge gained through interviews, the evaluation was also informed by pre-existing information available in project documentation, including letters of agreement, project plans, an intervention logic model (previous presented as figure 2) and existing monitoring and evaluation reports. These documents were provided by ACC and consisted largely of qualitative information. The review of documentation was used to assist in identifying to what extent delivery of the approach aligned with what is already known from the literature about what works best for Māori. The evaluative processes included reviewing the original logic model to assist ACC in updating the model. Logic model review findings are not included in this article.

Project documents provided by ACC to the evaluation team were also thematically analysed using a deductive or theory-driven process, whereby existing theoretical models were used to frame and interpret data. This enabled the evaluation team to determine how the 'My Home is My Marae' approach aligned with existing models of Māori healthcare, and expectations that Māori have of ACC.

Quantitative data were also provided by ACC in Excel documents, which detailed the number of whare visited, age of whānau present during the home safety audit, total number of whānau living in the home, hazards identified and solutions to hazards suggested. This was analysed through basic statistical analyses such as calculating the total number of whare visited, total number of whānau included, total number of hazards identified and per cent of hazard types, locations and solutions applied.

\section{RESULTS}

Five critical success factors underpinning 'My Home is My Marae' were developed from analysis of the kōrero: (1) Mana tangata, (2) manākitanga, (3) kānohi-ki-tekānohi, (4) capacity building for kaimahi, whānau and providers and (5) 'low cost/ no cost' solutions to hazards in the home, which are discussed below.

\section{Mana tangata and manākitanga}

Across kaikōrero, a powerful and consistent message emerged: the importance of having the right people at ACC and in the community to support and deliver 'My Home is My Marae'. Having the 'right' people facilitated (1) buy-in from provider organisations to deliver the programme in local communities, (2) engagement and credibility with local communities and (3) the integrity of a 'by and for Māori' approach to injury prevention. 'My Home is My Marae' was led by ACC's injury prevention consultants who are kānohi kitea and deeply respected by staff from provider organisations. Provider commitment to delivering the 'My Home is My Marae' programme was secured by these consultants as a direct result of the mana tangata, or reputation, respect and credibility, of these individuals in Māori communities.

The injury prevention consultants acted as key conduits between ACC and provider organisations, managing kōrero between ACC and providers, delivering training and offering their commitment and support to kaimahi from provider organisations who delivered 'My Home is My Marae'. More importantly, however, the injury prevention consultants were well known and connected to local providers and communities in which the programme was delivered. As illustrated by the following quotes, for all providers, the mana tangata of the consultants-Hineamaru and Sandra-was pivotal in their decision to be a part of the journey in delivering 'My Home is My Marae':

The key is the relationships- and Hineamaru is the key for us and if it wasn't for Hineamaru then we wouldn't have taken part in this programme... ACC is lucky to have Hineamaru.

Everything we did we did through Sandra. Sandra was the conduit between ACC and us. We liked that it was Sandra, she was a great go to person, she understood us as Māori. 
If it was anyone other than Sandra to come and speak to us we would have said 'no, it's not worth it'...Sandra is trusted by us and she completed the training which was absolutely vital, she came back to the marae and did extra training - so that's one-to-one going that extra distance. That person is accountable to her marae, her whānau and to the [provider organisation].

Kaikōrero advocated that it is also vital to have "the right mix of providers and the right type of people chosen to go into the homes" to support whānau engagement. As described by one kaikōrero, the "My Home is My Marae' approach works because "The relationships and partnerships with whānau and community are at our level—they are ours."

Kaimahi observed a deep suspicion of government agencies among Māori communities, some of whom are "still fighting for the return of land-their distrust of government agencies [is high]." As such, ACC was not perceived by providers or whānau as a socially or culturally appropriate vehicle for the delivery of messages about home safety to whānau:

The perception of whānau is that the main agenda of ACC is to get whānau back into work after suffering injuries. Therefore, whānau are resistant to a relationship with ACC, whereas whānau have relationship with us as providers and as members of their community.

This distrust of ACC may also stem from poor previous experiences with claims processes ${ }^{4}$ and meant that kaimahi had to take time for whakawhanaungatanga: meeting, connecting, explaining the kaupapa and assuring whānau that kaimahi were there for the right reasons.

The providers enabled whānau engagement because kaimahi were local Māori, carrying local knowledge, speaking the right language, were personally connected to whānau through whakapapa and their residence in local communities and had the passion and integrity to deliver messages to whānau in a way that is mana enhancing; showing whānau that they are valued and cared for.

Kaimahi offered the programme unique characteristics that could not be replicated or reproduced directly by Māori who were not kānohi kitea, or by ACC as an organisation. These characteristics were manākitanga, local knowledge, community connection through whakapapa and local language:

If you don't know the whānau then you will get the door shut in your face! So having the relationships and trust with our whānau is important. We knew them through whānau and social circles and that's why the programme was acceptable.

Kaimahi have to be skilled in engaging with our local people. You have to speak their language and be a local. They will ask if you are a local, and if you say no, then you will be lucky if they talk to you. They want a connection and we have had to work at building this connection for many years.

As providers we all have the passion so we thrived doing this programme.

\section{Kānohi-ki-te-kānohi}

A unique part of the 'My Home is My Marae' approach was that it took place in the whare of whannau. This is a significant departure from previous approaches undertaken by ACC and providers and is fundamental to the approach being 'kaupapa Māori' as it allows for face-to-face engagement and whakawhanaungatanga with whānau: "This is not just about the project, this is about creating conversations and talking with our people within the home."

While reflecting on how health or injury prevention messages were delivered to whānau previously, one kaikōrero commented that:

[Before] it was health promotion stuff, standing at a sports event, handing out panui, having wānanga. Whānau will be picky and come and not retain anything at all. It wasn't very effective. It was a waste of resources. You never really had the opportunity to engage with the whānau and see what it actually looked like at their whare. Pamphlets were only given-that's what it used to be like.

In contrast, 'My Home is My Marae' gave kaimahi the opportunity to engage with whānau more meaningfully kānohi-ki-te-kānohi in their whare. Kaimahi were grateful for and humbled by this opportunity and recognised the value in connecting with whānau to create opportunities for further work in promoting their health and well-being:

The project gave us a reason to go into the homes and meet with whānau. We cannot just go into the homes and look around and inspect as this is disrespectful. This project has enabled us to go into the homes and talk with our [whānau] and say we are doing this project, [we need] your help and this is the understanding of this project and why we are here.

However, not all whānau were receptive to the face-to-face approach within their whare. Some required assurance from kaimahi or preferred to engage within different community settings beyond the home such as the marae. Reportedly, however, kānohi-ki-te-kānohi was generally of preference to whānau and was particularly advantageous when engaging with whānau who needed assistance to complete surveys or checklists. The approach was also of particular value to whānau when someone close to them had experienced an injury in the past:

The whānau enjoyed having us in their whare and were open to the project due to someone in their whānau (especially their kaumatua) having a fall. The kōrero was 
the whānau were extremely grateful to have this opportunity because the dangers or the awareness of dangers in the home have been looked at for their homes.

Kānohi-ki-te-kānohi repeatedly allowed for (1) kaimahi and provider organisations to better engage and connect with whānau, (2) kaimahi to develop a deeper understanding of the circumstances, home safety hazards and other health issues occurring in the homes of whānau and subsequently to (3) be more responsive to the unique needs and circumstances of whānau, and to hazards in the home (increased responsiveness).

\section{Capacity building for kaimahi and whānau}

Building capacity among kaimahi and whānau was a key strength of the 'My Home is My Marae' approach and has occurred in two key ways: increasing the capacity of kaimahi through a train-the-trainer or tuakana-teina approach to training; and empowering whānau to address hazards through changes in their knowledge about hazards in the home.

Training was delivered to kaimahi to complete home safety audits collaboratively with whānau. Kaikōrero indicated that training was highly valuable in providing kaimahi with the knowledge they needed. During the training, kaimahi "looked at the principles of the programme and had to familiarise ourselves with its resources. We also had to become competent and confident within ourselves and the kaupapa first." This illustrates the professional and spiritual journey kaimahi took to learn and apply their new knowledge to make homes a safer place for whānau. The spiritual aspects of their work became more pronounced as kaimahi entered the homes of whānau and became aware of the many hazards and other challenges whānau may encounter in their daily lives. Observing poverty was something that kaimahi carried spiritually as they sought to support and empower whānau with needs that often fell beyond the scope and resources of 'My Home is My Marae'.

The tuakana-teina model supports sustainability of the 'My Home is My Marae' approach not only by equipping kaimahi with knowledge around reducing hazards in the home, but also by building leadership and capacity among whānau and rangatahi. As explained by one kaikōrero:

\footnotetext{
The good thing about it is that we are not only talking about the awareness with just the mothers and fathers, it's with the kids-the mokopuna, koroua, and kuia. So this has shown the togetherness and connectedness of the whānau and it has created a wider awareness and a greater involvement of the dangers within the home.
}

Observing the impact their work had on whānau was inspiring for kaimahi. Although measurement of changes in knowledge or awareness among whānau was out of scope of this evaluation, kaimahi reported observing that the approach created awareness among whānau about hazards in the home:

Whānau didn't realise the potential consequences of the hazards in their homes because it had never been explained to them. They never thought about hazards because it is the 'norm' in whānau homes (that is, it is normal to have these 'hazards' in the home as they are not perceived nor recognised as hazards). So this programme was great in that sense that it explained what hazards are and created this awareness for whānau. It was an eye opener for whānau about potential hazards in their homes.

The upskilling of whānau promoted tino rangatiratanga in protecting whakapapa. This capacity building of whānau also meant that the providers could "call on whānau that we already have engaged to do the mahi and be facilitators of the programme. They are applying this teaching and these practices within their homes." The approach aimed to be inclusive of all whānau members, from tamariki to tūnohunohu, who could take action to minimise, eliminate, isolate or reduce hazards.

\section{'Low or no cost' solutions to hazards in the home}

'My Home is My Marae' is predicated on implementing 'low or no cost' solutions to hazards in the home. Comments from whānau captured in project documentation stated that "financial costs were the greatest barrier to change" (Tamaki Makaurau Māori Women's Welfare League, 2016). The ability for whānau to reduce hazards in their home with little or no financial cost was a key strength of this approach, particularly when addressing hazards in low-income households.

Hazard auditing in Far North whare showed that $76 \%$ of the hazards identified and recorded in the whare of whānau could be resolved through 'low or no cost' solutions (368 of 481 hazards). $23 \%$ of the hazards encountered could not be resolved through low or no cost solutions (113 hazards). These unresolved hazards required a high-cost solution such as plumbing and electrical work ( $16 \%$ or 79 of 481 hazards), other unspecified solutions ( $6 \%$ or 30 of 481 hazards) or had no solution identified ( $1 \%$ or 4 of 481 hazards). Unfortunately, these data were not available for South Auckland.

\section{DISCUSSION}

This evaluation explored critical success factors of ACC's 'My Home is My Marae' injury prevention approach and identified mana tangata and manākitanga, kānohi-ki-te-kānohi, capacity building and the implementation of 'low or no cost' solutions as integral to the approach and engagement of whānau and/or Māori communities. The evaluation also aimed to understand these factors in the context of what is known to work 
well for Māori in injury prevention, and Māori models of health and well-being.

Having the 'right people' to support and deliver 'My Home is My Marae' extended from strong Māori leadership at ACC who facilitated buy-in from provider organisations, to frontline staff who were locally informed, present and connected. As trainers, advocates and key conduits between ACC and Māori providers, Māori leaders at ACC are a key support system for kaimahi. Coggan et $a l^{14}$ emphasise the importance of strong Māori support networks and cultural competency of project co-ordinators. Their evaluation of the Waitakere Community Injury Prevention Project highlighted the pivotal role the Māori Coordinator played in building strong support networks for the project at the local marae. The current evaluation showed that without key Māori representation at ACC, providers would have been reluctant to participate. The networks, relationships and trust that the injury prevention consultants were able to leverage to secure provider involvement in 'My Home is My Marae' were a key strength of this approach. However, this same strength also presents a challenge for the future growth of 'My Home is My Marae'. Increased Māori representation at ACC is needed to enable succession planning, growth and increased sustainability of the approach.

Beyond Māori leadership, kaimahi-equipped with their care and passion for communities, and local knowledge, language and connection-delivered home safety messages with credibility. A previous evaluation of the Ngāti Porou Community Injury Prevention Project highlighted the importance of staff having strong community ties. ${ }^{15}$ The project involved working with a rural Māori community in the North Island to deliver road safety campaigns, alcohol and drug programmes and family violence initiatives. It connected with Māori (kānohi-ki-te-kānohi) in hui at various local settings such as marae, Māori immersion schools and sports clubs and achieved a significant increase in awareness of injury prevention among participating whānau: (pre 17\% and post $25 \%, \mathrm{p}>0.05$ ). Post-intervention, whānau were more likely to agree that alcohol-related injuries are preventable (pre 2\%, post 10\%). Evaluators positioned the establishment of strong community ties as pivotal to the project's success. ${ }^{15}$

Through local Māori providers, the delivery of home safety messages for 'My Home is My Marae' reflects a 'for and by Māori' approach that enhances whānau engagement and importantly assists in (re)building ACC's relationship and reputation with Māori communities. This is particularly significant given the distrust of ACC among Māori communities. ${ }^{4}$ A systematic review by Klassen et $a l^{16}$ showed that injury prevention programmes are generally more effective when they are tailored to address unique community characteristics, such as ethnicity and socioeconomic status. The 'My Home is My Marae' approach achieves this through localisation of Māori providers with strong community ties, but provides nationally standardised ACC resources (eg, checklist and teaching aids). This evaluation identified an opportunity for injury prevention initiatives to authorise tailoring of resources to address unique community needs, effectively (1) increasing provider autonomy to develop or amend resources, and further (2) supporting increased visibility of provider organisations (eg, through incorporation of provider organisation branding).

Brewin and Coggan ${ }^{15}$ also attributed the success of the Ngāti Porou Community Injury Prevention programme to how the project addressed Māori aspirations. While 'My Home is My Marae' creates strong community ties through the contracting of frontline delivery to local Māori providers, the approach fails to connect with/ address higher level Māori aspirations for improved wellbeing and reduced health inequities experienced by Māori communities. A focus on 'low or no cost' solutions enables whānau to address minor household hazards in an affordable way. However, broader social causes impacting the state of housing and health and well-being of whānau are not addressed within the scope and resources for 'My Home is My Marae'. Observations of poverty and poor housing states experienced by some whānau are carried on the wairua of kaimahi whom, beyond their contracted roles, continue to act as advocates for whānau to have high costs hazards and/or substandard housing addressed. Typically, this requires the attention and involvement of stakeholders outside the whānau (such as landlords) and support for whānau to navigate government agencies.

Through home safety auditing, kaimahi aimed to increase whānau knowledge of hazards in their whare so that these can be effectively reduced, isolated or eliminated ('capacity building'). This multifaceted approach to intervention addresses behavioural (knowledge and awareness of whānau to reduce or eliminate hazards) and environmental (changes made in whare) dimensions. This reflects, to some extent, a more holistic approach to health that better aligns with Māori approaches and understandings of health and wellbeing. Towner and Doswell's research ${ }^{1}$ was not specific to whānau, but highlighted the importance of stimulating cultural change through a mix of environmental and behavioural intervention for injury prevention. That is, community-based injury prevention efforts should aim to create/build knowledge, but also act on knowledge or create environmental changes. A New Zealand study $^{17}$ that measured falls at home requiring medical treatment (per person, per year) attributed environmental changes in homes, including the fastening of "handrails along outside steps and internal stairs, grab rails for bathrooms, outside lighting, edging for outside steps, and slip-resistant surfacing for outside areas such as decks and porches" (p. 231), to a $26 \%$ reduction in the rate of injuries caused by falls at home per year.

Cherrington and Masters ${ }^{18}$ provided a review of Māori models of health in previous work prepared for injury prevention at ACC and identified three models-Te 
Whare Tapa Whā, Ngā Pou Mana and Te Wheke-which are regarded as emulating tikanga practices. Cherrington and Masters identified common features of models and frameworks to be a focus on holistic approaches and "acknowledgement of wairuatanga (spirituality) and whānau (family)" [ref. 18, p. 2]. Drawing from these Māori models of health, 'My Home is My Marae' takes a preventative approach that is whānau inclusive (reflecting the hauora of the whānau), whānau empowering (improving knowledge and awareness of whānau to reduce, eliminate or isolate hazards in their whare), environmental (making changes in the homete oa turoa) and physical (reducing the risk or incidence and/or severity of injury in the home-te taha tinana). The aim of empowering and motivating whānau is particularly aligned to dimensions of te taha whānau (family well-being) and whanaungatanga (the extended whānau and social interactions).

From previous research, we concluded that the "My Home is My Marae' approach aligns well with what is known to work for Māori in injury prevention for several aspects including leveraging strong community ties, being whanau inclusive, creating and sharing awareness/knowledge, maintaining strong Māori leadership and delivering a multifaceted intervention which simultaneously addresses environmental and behavioural dimensions (educating and acting). Key challenges and opportunities for the future development of 'My Home is My Marae' identified in this article include increased Māori leadership at ACC, resourcing to address Maori aspirations of 'My Home is My Marae' and tailoring of resources to address unique community needs.

There were some limitations to our Kaupapa Māori evaluation of 'My Home is My Marae' trials. In many instances, kaimahi shared the perspectives or experiences of whānau, but the evaluation did not involve the direct participation of whānau who had completed home safety audits alongside kaimahi. In addition, provider organisations that participated in this evaluation were selected by ACC and it is possible that provider organisations not involved in the evaluation could have had different experiences that were not captured. While low or no cost solutions used in this programme were identified as potentially highly cost-effective for ACC, a specific costbenefit analysis was not carried out-this may be a direction for future research. Finally, incomplete quantitative data in Excel spreadsheets meant that it was not possible to draw robust conclusions regarding the reach of the programme and also presented difficulties in being able to compare different patterns in the hazards identified across Far North and South Auckland regions.

\section{CONCLUSIONS}

'My Home is My Marae' is a multifaceted approach to intervention that addresses behavioural (knowledge and awareness of whānau to reduce or eliminate hazards) and environmental (changes made in whare) dimensions. The Māori leadership and mana tangata of ACC's injury prevention consultants acting as conduits between ACC and provider organisations, and securing provider's engagement, were key strategic factors for success. Programme delivery by local Māori organisations provided the opportunity to integrate injury prevention in other health promotion activities by these organisations; facilitating a holistic rather than isolated response to whānau needs.

'My Home is My Marae' reflects a holistic approach to injury prevention which (to varying extents) aligns with Māori tikanga and Māori models of health and wellbeing-specifically in that the approach is whānau inclusive (reflecting the hauora of the whānau), whānau empowering (improving knowledge and awareness of whānau to reduce, eliminate or isolate hazards in their whare), environmental (making changes in the homete oa turoa) and physical (reducing the risk or incidence and/or severity of injury in the home-te taha tinana). Injury prevention or health promotion approaches that seek to engage with whānau and/or Māori communities would benefit from realising critical success factors of 'My Home is My Marae'.

Acknowledgements The authors express a deep appreciation to kaikōrero from provider organisations who contributed to this evaluation kōrero-from Management to kaimahi who deliver the approach in the whare of whānau. Your passion and enthusiasm to support whānau is an inspiration to the evaluation team and an asset to ACC and Māori communities. They also thank whānau who so courageously let kaimahi into their homes to tackle hazards head on and make changes for the safety of our whānau—kuia, kororua, pākeke, tamariki and mokopuna. Heoi anō kia ACC mō o koutou tino tautoko I tēnei kaupapa whakahirahira "Ko tōku kainga, tōku marae". Kia ora anō ACC mō o koutou tautoko I tēnei waitara me te whakanui I te kaupapa. No reira, he mihi mahana anō kia tātou katoa.

Contributors This article has been principally developed by the Research and Evaluation Office of Ko Awatea, Counties Manukau Health: BH, DM, LL and LV. ML also contributed to the article development. AE-H of OTS Consulting was the Kaupapa Māori consultant for this evaluation. BH managed the evaluation process including the development of participant documents, data analysis, evaluation reporting and partnerships with stakeholders. ML was the interviewer for the evaluation and also contributed to the development of information sheets, co-analysed interview data and reviewed evaluation reporting. LV developed the evaluation framework in partnership with ACC and reviewed evaluation reporting. DM drafted the paper and analysed home audit data. AE-H provided cultural knowledge and support as a kaupapa Maori expert and ensured integrity of information sheets, evaluation processes and evaluation reporting. LL reviewed all evaluation documents.

Funding The kaupapa Māori evaluation of 'My Home is My Marae' was funded and supported by the Accident Compensation Corporation (ACC),

Wellington, New Zealand. Views and/or conclusions in this report are drawn from the analyses of evaluation data completed by Ko Awatea's Research and Evaluation Office (Counties Manukau Health) and may not reflect the position of ACC.

Competing interests The authors declare that they have no competing interests.

Ethics approval Ethical approval to conduct this evaluation was granted by The ACC Ethics Committee. The ACC Ethics Committee is made up of a mix of ACC staff and external representatives who review ACC's research methods to ensure the rights and interests of ACC clients and stakeholders are protected. All participating kaikōrero provided written informed consent to participate in this evaluation. 
Provenance and peer review Not commissioned; externally peer reviewed.

Data sharing statement 'My Home is My Marae' data are not available from Ko Awatea. Interested parties should refer to ACC with data requests. New Zealand injury data are publically available from http://www.acc.co.nz/ about-acc/statistics/.

Open Access This is an Open Access article distributed in accordance with the Creative Commons Attribution Non Commercial (CC BY-NC 4.0) license, which permits others to distribute, remix, adapt, build upon this work noncommercially, and license their derivative works on different terms, provided the original work is properly cited and the use is non-commercial. See: http:// creativecommons.org/licenses/by-nc/4.0/

\section{REFERENCES}

1. Towner E, Dowswell T. Community-based childhood injury prevention interventions: what works? Health Promot Int 2002;17:273-84.

2. Laflamme L, Sethi D, Burrows $\mathrm{S}$, et al. Addressing the socioeconomic safety divide: a policy briefing. Copenhagen: WHO Regional Office for Europe, 2009:38.

3. Ministry of Health. Tatau Kahukura: Maori Health Chart Book 2010. 2nd edn. Wellington, New Zealand: Ministry of Health, 2010:77.

4. Māuri Ora Associates. Maori experience of ACC: Mauri Ora associates final report for Department of Labour. Auckland, New Zealand: Mauri Ora Associates, 2010:92.

5. Wyeth EH, Derrett S, Hokowhitu B, et al. Indigenous injury outcomes: life satisfaction among injured Māori in New Zealand three months after injury. Health Qual Life Outcomes 2013;11:120
6. Accident Compensation Corporation (ACC). Injury statistics tool [internet]. Wellington, New Zealand: ACC, 2015 [cited 1 Dec 2016]. http://www.acc.co.nz/about-acc/statistics/injury-statistics-tool/index.htm

7. Statistics New Zealand, Office for Disability Issues. Disability and Māori in New Zealand in 2006: results from the New Zealand Disability Survey. Wellington, New Zealand: Statistics New Zealand, 2010:36.

8. Bushe GR. Appreciative inquiry: theory and critique In: Boje D, Burnes B, Hassard J, eds. The Routledge companion to organizational change. Oxford, UK: Routledge, 2011:87-103.

9. Smith L. Decolonizing methodologies: research and indigenous peoples. London, UK: Zed Books, 1999.

10. Te Ropu Whariki. The evaluation hikoi: a Maori overview of programme evaluation. Auckland, New Zealand: Massey University, 2009.

11. Kerr S. Kaupapa Māori theory-based evaluation. Evaluation J Australasia 2012;12:6-18.

12. Boyatzis RE. Transforming qualitative information: thematic analysis and code development. London: Sage, 1998:184.

13. Guba E, Lincoln Y. Effective evaluation. San Francisco: Jossey Bass, 1983.

14. Coggan $\mathrm{C}$, Patterson $\mathrm{P}$, Brewin $\mathrm{M}$, et al. Evaluation of the Waitakere community injury prevention project. Inj Prev 2000;6:130-4.

15. Brewin M, Coggan C. Evaluation of the Ngâti Porou community injury prevention project. Ethn Health 2004;9:5-15.

16. Klassen TP, MacKay JM, Moher D, et al. Community-based injury prevention interventions. Future Child 2000;10:83-110.

17. Keall MD, Pierse N, Howden-Chapman P, et al. Home modifications to reduce injuries from falls in the Home Injury Prevention Intervention (HIPI) study: a cluster-randomised controlled trial. Lancet 2015;385:231-8.

18. Cherrington L, Masters B. Literature review of Maori models of health and indigenous injury prevention and health promotion interventions. Prepared for Ronald Karaitiana, Cultural Strategies Manager, Injury Prevention. Wellington, New Zealand: Accident Compensation Corporation, 2005. 